Petlyuk Yuriy,

$\mathrm{PhD}$ (Law Sciences), Kyiv National University of Trade and Economics, 19, Kyoto str., Kyiv, 02156, Ukraine

ORCID: 0000-0003-4601-3862

\title{
THE GIST AND ROLE OF LOCAL TAXES IN THE FUNCIONING OF INITED LOCAL COMMUNITIES
}

An analysis of local taxation is given and the ways of improving the legal regulation of filling budgets united local communities through the recovery of national and local taxes and fees are proposed.

Key words: revenues of the local budgets, national and local taxes and fees, combined communities, government, and financial capability.

\section{Петлюк Юрій. Сутність і роль місцевих податків об’єднаних тери- торіальних громад.}

Наведено аналіз місиевого оподаткування та шляхи вдосконалення правового регулювання наповнення бюджетів об'єднаних територіальних громад иляхом стягнення національних і місцевих податків та зборів.

Ключові слова: доходи місцевих бюджетів, наиіональні та місиеві податки і збори, об'єднані громади, державні та фінансові можливості.

Relevance of the research topic. Local government is one of the components of power in Ukraine and is intended to provide economic development, creating conditions for the life and welfare of the population at the local level. Nowadays, the political vector of our country is strengthening the role of local government through decentralization and the establishment of all necessary legal, social, economic, political and other conditions for the operation and the development of united communities.

Analyzing the historical experience of social development, it should be noted that the efficiency of power can be achieved only if there is interdependence of these, in our opinion, main social components as the current law to establish accountability and ensure its holding by means of state coercion, as well as provision of financial and economic capacity.

Analysis of recent research and publications. So far, the analysis of legal regulation of filling the budgets of different levels through tax and other financial mechanisms implemented in a large number of scientific articles and monographs. 
Scientific and theoretical basis for relevant studies are the works of famous domestic experts in finance - E. O. Alisov, L. K Voronova, A. P. Hetmanets, A. A. Dmytryk, I. B. Zaveruha, V. I. Kurylo, M. P. Kucheriavenko, O. A. Lukasheva, O. A. MuzykaStefanchyk, V. V. Mushenok, A. A. Nechay, O. P. Orlyuk, P. S. Patsurkivskyy, M. O. Perepelytsya, N. Y. Pryshva, V. D. Chernadchuk and others. However, initiated in Ukraine the reform of local government in the establishment of united local communities requires from the representatives of legal science new research in terms of building an efficient mechanism of fiscal ensure of these communities.

The purpose of this study is a comprehensive analysis of the current tax regulatory framework from the point of view of mechanisms of formation of financial capacity of local governments in the process of reforming in the current trend of decentralization and unification.

Results of the research. First of all, pay attention to the fact that the European Charter of Local Self-Government states that local authorities should have the necessary amount of own sources to carry out the powers.

Pursuant to paragraph 3 of article 9 of the Charter, at least some part of financial resources of local authorities should be received from local taxes and fees, rates of which are determined by these authorities as permitted by law.

The issue of improvement the process of formation the local budgets and search for reserves of their increasing is extremely important during the building process of independence of our country, because over the years there is a negative trend to reduce the share of own source revenues in the structure of local revenues and, consequently, increasing the number of subsidized budgets. Lack of stable own revenues significantly limits the impact of local government on socio-economic development of their areas. Expanding and optimizing sources of local budgets is an extremely important task, the solution of which will increase the level of financial independence and stability of united local communities and qualitative performance of their tasks and functions.

Based on the above specified problem and despite the fact that in the article № 142 of the Constitution of Ukraine and other normative-legal acts (Budget Code (1) the tax code of Ukraine (6), the law of Ukraine «about local government in Ukraine» (3)), the legal and financial basis of local government is enshrined we consider that one of the priority and important tasks of modern policy of decentralization of power is the reform of budget-tax system of local self-government bodies. As in the past and at present, the functioning of local self-government bodies in most local communities does not ensure the creation and maintenance of an enabling environment for the comprehensive development of human being, its fulfilment and protection of its rights.

The world practice shows that local budgets revenues are formed using the sources of financial resources and local taxes and fees constitute irremissibly a certain part in the financial capability of the local self-governance. It is clear that amid slumping amounts of central funding the problem of filling of local budget revenues 
becomes most prominent. The most rational solution to this problem is to broaden the powers of local authorities and to reform the local tax system. The strive to accomplish this goal itself led to numerous attempts of altering the legal framework regulating local taxation in the years of building the financial and budgetary system of Ukraine (2, p. 15).

In order to overcome these problems in Ukraine the reform of local government is declared and its main trends are identified in the Concept of reforming the local selfgovernment and territorial organization of power in Ukraine, which aim is to determine trends, mechanisms and timing of the formation the effective local selfgovernment and territorial organization of power to create and maintain full living environment for citizens, establishment of institutions of direct democracy, satisfying the interests of citizens in all spheres of life in the territory, reconciling the interests of the state and local communities (7).

In our opinion, giving a right to local authorities determine tax rates without fixing their upper limit is not reasonable, because above all things it makes orienting in tax rates of different territorial communities difficult for a taxpayer which noticeably influences his activity and tax planning in particular. At the same time, such a system has certain advantages, which the USA's experience proves rather persuasively. In this country some tax rates for each level are determined by the legislation, other are determined by municipalities or states, in particular, real estate, sales tax rates. The tax level influences noticeably the business activity in territorial communities, ensuring the establishment of an attractive investment climate. But market mechanisms even rates of such taxes on different territories in the conditions of the stable economy. And, what is really important, in circumstances when risks of deterioration or destabilisation of the economic situation arise and when special aims appear local authorities can easily correct elements of the taxation system. Therefore, local taxes can and have to be used as an efficient instrument of regulation.

Analysis of socio-economic, organizational and managerial realities in the system of local government shows that the main cause improper situation is the lack of effective funding sources of local communities. Therefore, first of all, system of local taxes, fees and boards should be reformed as major excipients of local budgets are tax payments. Before you give your own suggestions of improving the legal framework of the tax system, in our opinion, it will be appropriate to analyze the tax payments credited to local budgets over the past two decades (4, p. 147).

Coming into being and development of local taxes and fees began with Ukraine becoming independent, even before the ratification of the European Charter of Local Self-Government. In 1990, the law of Ukraine «On councils of people's deputies and local and regional self-governance» had been passed, giving the power for imposing taxes and fees to the competence of the basic level councils (rural, village and town councils). This broadened financial capabilities of local councils in terms of ensuring economic the self-dependence in the respective administrative-territorial entities. 
The passing of the law of Ukraine «On taxation system» and the decree of the Cabinet of Ministries of Ukraine «On local taxes and fees may be considered a key moment in the legal establishing of the institute of local taxes and fees. These documents defined the legal principles of exercising the fiscal powers by local authorities» (5, p. 129).

Starting from 2011, the system of local taxation was reorganized by adopting the tax code and amendments to the list of local taxes and fees (6). Innovations in the mechanism of local taxation have led to both positive and negative changes in this part of the revenues of local budgets.

There are the following achievements of the Tax code of Ukraine:

- abolishing a number of fiscally inefficient tax payments;

- simplifying the administration system of local taxes;

- putting in order powers of local authorities in terms of imposing and administrating local taxes and fees by limiting unrestricted interpretation of their administration procedure by local authorities;

- regulation of the interaction between local and controlling authorities;

- imposing the real estate tax considered in the majority of the European countries the most effective one;

- granting the status of a local tax to the single tax allowing to broaden the financial independence of local budget.

Starting from 01.01.2015, according to the article 10 of the tax code of Ukraine, local taxes include a tax on property and a flat tax and local fees - charges for parking vehicles; tourist tax. Local councils establish a tax on property in the part of the vehicle tax and land tax on real property, other than lot of land. Establishment of local taxes and fees not stipulated by the tax code of Ukraine is forbidden. Enrollment of local taxes and charges made to the relevant local budget (3).

However, the local taxation system, as one of the main sources of formation of the financial base of local self-government, is not covered by the necessary changes, in particular, in the creation of appropriate material, financial and organizational conditions for full-fledged self-government. Government and delegated authority through the use of local taxes and fees. The concept of reform of local governments and territorial authorities only suggested: ensuring the right of such bodies to regulate rates of local taxes and fees, and also proclaimed the right to establish benefits only to the local government whose budget included such payments (4, p. 148).

In our opinion, only such changes will not lead to increase the financial base of local budgets to the required level of expenditures, and the strategy of reforming the current system in the country today, local taxes and fees in the first place, should comply with the principles of the European Charter. In particular, the serious problem is that embodied in the tax code of Ukraine, local taxes and fees and rates do not take into account the real possibilities of taxpayers, and therefore do not perform the 
enabling functions. Such shortcomings affect the observance of the principles of unity, completeness, authenticity, openness, clarity of the budget structure of local communities and the country as a whole.

It is possible to radically improve the local taxation system, which is part of the state's tax system and at the same time a necessary financial feature of local selfgovernment, provided that a number of systemic shortcomings are overcome, including: author:

- the small fiscal role of local taxes and fees and, as a result, their low share in local budget revenues;

- lack of an effective legal framework that would meet current economic conditions;

- lack of rights of local authorities to exercise their own taxes and fees on their territory;

- inferiority of local taxes and fees compared to general ones;

- a short list of local taxes and fees compared to other countries.

To solve the problems in the formation of local budgets in Ukraine one should propose their solutions are:

- to improve the existing normative-legislative framework with the goal of more effective regulation of the process of formation and use of financial resources in local budgets combined territorial communities;

- to make a gradual transition for decentralization of the management of local budgets which will give an opportunity for local finance to become more independent institute;

- to reform of local taxation in the transfer of some of the taxes from the category of national local and install a more fair distribution of interregional share of taxes;

- to implement exercise control over formation and the local budgets of the community.

Conclusion. Thus, the successful development the process of formation the local finance as an effective tool in guiding the work of the united local communities in Ukraine is possible only under the condition of the general administrative and financial reforms, the result of which should be the formation of a new, modern organization of state power and local self-government, restructuring inefficient financial and fiscal and tax systems in the country.

To reform the native system of local taxation one needs to ascertain which from the above-mentioned model is the most effective in the modern conditions. The question concerning the right of local authorities to impose taxes and fees as they deem appropriate needs further scientific investigation. In our opinion, it is rational to give that right to bodies of power of consolidate territorial communities since the local finance system cannot be independent if local authorities do not have a tax autonomy, 
if separate objects of taxation for local taxation are not distinguished from the array of objects of taxation. That is why it is necessary to give to bodies of power of consolidate territorial communities the right to impose own taxes and fees and to autonomously determine tax rates (provided it is controlled by the national bodies of the general taxation level).

\section{REFERENCES}

1. Byudzhetniy codex Ukrayiny № 2456 -VI vid 08. 07. 2010 [Budget Code of Ukraine] // Vidomosti Verhovnoi Rady Ukraine [Supreme Council of Ukraine]. (2010), 50-51, 230.

2. Buriachenko A. E., Palii M. P. Improvement of financial mechanism of local budgets. Finance Ukraine. 2008. № 8. P. 13-18.

3. Zakon Ukrayiny «Pro mistseve samovryaduvannya v Ukraini № 280 /97VR vid 21.05.1997 [Law of Ukraine «About local self-government in Ukraine»]. // Vidomosti Verhovnoi Rady Ukraine [Supreme Council of Ukraine]. (1997), 24, 150.

4. Kurylo V. I., V. V. Mushenok (2016). Znachennia mistsevykh podatkiv u reformi mistsevogo samovryaduvannia v Ukraini. Abstracts of Papers. Aktual'ni problemy rosvytku intelektualnykh i industrialnykh parkiv. (pp. 146-149). Kyiv. [in Ukraine].

5. Naumenko A. M. Directions of improving yield of the local budgets. State and regions. 2009. № 5. P. 127-133.

6. Podatkoviy codex Ukrayiny № 2755-VI vid 02.12.2010 [Tax code of Ukraine] // Vidomosti Verhovnoi Rady Ukraine [Supreme Council of Ukraine]. (2011), 13-14, 15-16, 17, 112.

7. Rozporyadzhennia Cabinetu Ministriv Ukrayiny «Pro zatverdzhennia konseptsii reformuvania vlady ta terytorialnoi organizatsii v Ukraini № 333 vid 01.04.2014 [Ordinance of the Cabinet of Ministers of Ukraine «On approval the concept for the reform of local self-government and territorial organization power in Ukraine»] // Ofitsiinyi visnyk Ukraine [Official herald of Ukraine]. 